\title{
Method for assessing the obsolescence of manufacturing equipment based on the triple bottom line
}

\author{
Marcelo Niehues Schlickmann ${ }^{\mathrm{a}}$ (D), João Carlos Espíndola Ferreira ${ }^{\mathrm{a} *}$ (D), Abner do Canto Pereira ${ }^{\mathrm{a}}$ \\ aDepartamento de Engenharia Mecânica, Universidade Federal de Santa Catarina, Florianópolis, SC, Brasil \\ *j.c.ferreira@ufsc.br
}

\begin{abstract}
Paper aims: This paper proposes a method for the assessment of equipment obsolescence, which includes the economic, environmental and social dimensions that compose the triple bottom line.

Originality: This paper describes a novel method that allows a complete evaluation of the state of use of a machine, besides the traditional economic-functional analysis, as well as its application in a large electric machines manufacturing company.

Research method: Analytic Hierarchy Process (AHP) multicriteria analysis is used, allowing a comparative and flexible assessment of the equipment.

Main findings: Even if there is no economic justification for replacing the equipment considering the financial return on investment, the machine can be considered obsolete from a sustainable point of view, due to its inadequate environmental and social performance.
\end{abstract}

Implications for theory and practice: Applying sustainability concepts in the manufacturing environment, more precisely in the machines on the shop floor, is very important to ensure cleaner production.

Keywords

Sustainable manufacturing. Equipment obsolescence. Triple Bottom Line (TBL). Analytic Hierarchy Process (AHP).

How to cite this article: Schlickmann, M. N., Ferreira, J. C. E., Pereira, A. C. (2020). Method for assessing the obsolescence of manufacturing equipment based on the triple bottom line. Production, 30, e20190003. https://doi.org/10.1590/0104-9224/S125.25

Received: Jan. 22, 2019; Accepted: Jul. 07, 2020.

\section{Introduction}

In recent years it is observed a high pressure on companies to consider not only the economic perspective of their processes and products, but also environmental and social aspects (Trianni et al., 2019; Qorri et al., 2018; Teles et al., 2016; Ortas et al., 2015; Pimenta \& Gouvinhas, 2012). As such, basic business activities such as purchasing, manufacturing, transportation, and sales nowadays need to be in tune with the three dimensions of sustainability (Paine, 2014). Manufacturers must have as one of the corporate objectives to support products and manufacturing processes that minimize environmental impacts and maintain good social practices and economic gains from the activities carried out. This endeavor has been understood by many customers who want their products to be produced sustainably (Brockhaus et al., 2016; Hallstedt et al., 2013; Haanaes et al., 2011). This has challenged industries around the world to remain competitive in the market by developing and implementing sustainable manufacturing techniques (Kushwaha \& Sharma, 2016, Thanki et al., 2016), even in industry 4.0 (Chaim et al., 2018). Thus, manufacturers have begun to search for solutions for sustainability measurement, yet there are not many effective measurement methods to assess the impacts of manufacturing on the environment and society (Joung et al., 2013). To further pressure companies, the UN Summit on Sustainable Development was held in 2015, where the Sustainable Development Goals (SDG) (United Nations, 2015a) were established. Among the 17 objectives, the 12th corresponds to Responsible Consumption and Production, which addresses, among other issues, the importance of strengthening the scientific and technological capacities of the countries towards more sustainable production patterns (United Nations, 2015b). 
In this context, this paper proposes a method to assess manufacturing equipment, based on the triple bottom line (TBL). The proposed method was applied for obsolescence assessment, using quantitative and qualitative sustainability indicators.

This paper is structured as follows. In section 2 a review of the knowledge used in this research is presented, which includes the triple bottom line and performance indicators, product obsolescence, and the AHP multicriteria analysis method. Section 3 describes the proposed assessment method, including the hierarchical structure used in the study. In section 4 the results of the application of the method are presented and discussed in the production of stator and rotor blades of a product manufactured in a large company. Finally, section 5 presents the conclusions of the paper.

\section{Brief literature review on the topics related to the proposed method}

\subsection{Triple Bottom line (TBL)}

The issue of sustainable development discussed by the Brundtland Commission (Brundtland, 1987) included the need to integrate aspects of environmental sustainability with economic and social aspects. Thus, it contributed to the definition of an important concept known as the Triple Bottom line. This concept was initially established by Elkington (1999), which incorporates social, environmental and economic dimensions in the assessment of sustainable development. The author points out the need to include sustainability in companies' daily life, and also the importance of harmonizing the traditional economic dimension with environmental quality and social justice (Elkington, 1999). These three dimensions are also known as 3P's (People, Planet and Profit) (Kleindorfer et al., 2005).

The literature review performed by Morioka \& Carvalho (2016) reports, based on the increase in the number of publications, that the inclusion of triple bottom line information in business performance indicators is quite significant in recent years. However, there are many opportunities for research, such as the search for more objective and tangible indicators for the social dimension.

Sustainability indicators provide a simple and affordable solution for rapid sustainability assessment. However, they have been rarely employed at the level of discrete manufacturing processes (Linke et al., 2013).

Robinson (2013) reports that Caterpillar, in addition to other large corporations, has set sustainability targets to be met in the coming years to guide them towards sustainable development. However, understanding the limitations and opportunities in discrete manufacturing processes are critical aspects of the path to achieve these goals. According to Robinson (2013), overall sustainability indicators (e.g. energy consumption, water consumption and waste generation) are usually well quantified within the plant. However, information at the manufacturing process level is not readily available.

\subsection{Equipment obsolescence}

The function of a manufacturing equipment or system is related to its ability to perform the tasks for which the equipment was produced (Sénéchal, 2017). In this context, Panneerselvam (2012) explains the gradual loss of this ability or, in other words, the process of equipment deterioration in two main aspects. The first is related to the incapacity of the components of the equipment to perform their functions, while the second relates to technological obsolescence. Incapacity is caused by physical changes through use, fatigue, wear etc., resulting in increased maintenance costs. The second may have a direct impact on the product and/or operators involved, due to the use of technologically obsolete equipment. With regard to the operators, in addition to excessive manual work compared with more modern equipment, the equipment may not meet new safety recommendations, which have been modified over time. Concerning the product, technologically obsolete equipment can influence directly the quality of what is produced (Guo, 2017).

Equipment obsolescence has been studied by many authors. Lawrence \& Tanchoco (1990) carried out a study to assess economic obsolescence for a multi-equipment environment, based on investment, production, and marketing information. Hartman \& Murphy (2006) explore if the economic life analysis for infinite-horizon equipment (including purchase, operating and maintenance costs), is a good policy for the finite-horizon problem, which occurs when companies only require an asset for a specified length of time, usually to fulfill a specific contract. Tan \& Hartman (2010) expand equipment replacement analysis for the case where the horizon

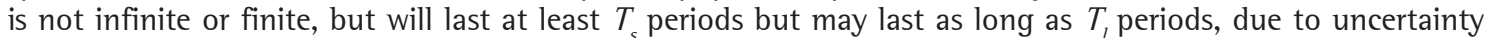
in the length of production runs or the temporary provision of services. Oliveira \& Duque (2011) used partial differential equations to indicate the moment for equipment replacement. Pingle (2015) proposed a model to evaluate obsolescence in a multicriteria decision environment, based on quantitative and subjective factors.

A common concern among these works is the special attention given to the economic dimension and eventually the environmental dimension is included for the assessment of obsolescence. The study by Sénéchal (2017) deals with the application of concepts related to the triple bottom line in assessing the depreciation of 
a piece of equipment. The author proposed a procedure to verify the sustainability condition of a machine as a function of monitored indicators, to assist in choosing the correct maintenance policy. The decision for replacing the equipment is made by comparing obsolete equipment with possible replacement alternatives (Ravi, 2015). According to Ravi (2015), when the relevant factors used in the comparison are converted to a financial basis, the best alternative can be chosen by applying economic evaluation methods. Among the existing methods, in this work the payback period assessment was used, which represents the time of economic return on investment resulting from the gain from equipment exchange. However, by not taking into account the cost of money over time, the more traditional evaluation method known as simple payback was replaced by the discounted payback period (Jan, 2017). The assessment carried out in this study was based on the assessment presented by Cucchiella et al. (2016), represented in Equation 1.

$$
\sum_{t=0}^{D P B T} \frac{C_{t}}{(1+r)^{t}}=0
$$

where $D P B T$ is the Discounted Payback Time, $t$ is the time of the cash flow, $C_{t}$ is the discounted cash flow, and $r$ is the opportunity cost. DPBT corresponds to the moment when the sum of the discounted cash flows $C_{t}$ values becomes equal to zero. It should be pointed out that the initial period $(t=0)$ the first cash flow represents the total amount invested in the equipment. For the following periods, the cash flows are obtained through the cash savings corrected accordingly by the opportunity cost $r$, which represents the cost of money at each period of the cash flow.

\subsection{Method of multicriteria analysis}

There are several methods of multicriteria analysis that are applied in different areas of knowledge. Huang et al. (2011) carried out a study based on 312 papers published between 2000 and 2009 describing researches related to decision making in the field of sustainability. According to Huang et al. (2011), the significant use of the AHP (Saaty, 1987) (48\%) can be explained by its ease of application and understanding by the decision maker, the greater availability of software, and the existence of user groups engaged in the subject.

More recently, Ho \& Ma (2018) report that among the techniques that support decision making, AHP is the most often used and well known for the last 20 years, because of its great flexibility and wide applicability. The authors reviewed articles published between 2007 and 2016.

Other studies related to the assessment of sustainability parameters also highlight the advantages of the AHP method. Among them is the study carried out by Caputo et al. (2013), where the AHP method is used in a safety assessment of equipment, leading to a significant robustness of the ranking obtained by the method, besides the advantage of the consistency analysis of the judgment made by the decision maker. Ocampo (2015) provides a model for the assessment of a computational index for sustainable manufacturing, where the AHP method integrates adequately both objective and subjective evaluations made in the assessment of the sustainability of a company. Kluczek (2016) presents the application of the AHP method in the assessment of sustainability in manufacturing processes, and the method is appropriate due to the possibility of comparing established criteria, as well as their mathematical simplicity and flexibility. And Saad et al. (2019) report that the AHP method is easy to use, scalable, easily adjustable to fit many sized problems, and it is not data intensive.

According to Saaty (2008), the decision making process using the AHP multicriteria analysis method must be performed in an organized manner, according to the following steps:

(a) Define the problem and determine the type of knowledge sought (overall objective of the assessment);

(b) Structure the hierarchical levels of assessment. Starting from the top, with the ultimate objective of the assessment, following the alternatives from a broad perspective, through intermediate levels, to the lowest level where usually is the set with the alternatives;

(c) Determine the two-way comparison matrices for each of the assessed alternatives, where each element at a level is used to compare with the elements at the level immediately below;

(d) Use the priorities obtained from the comparisons to assign weights to the priorities immediately below in the hierarchical structure. At the end, for each element of the level below, add the weighted values and obtain the total values for that level. This process must continue until the last level of the hierarchical structure.

In order to perform the comparisons, it is necessary to use a scale of numbers that indicates how important or dominant one alternative is over another in relation to the criterion or property to which these alternatives are compared. This scale can be obtained through a quantitative or qualitative assessment (Saaty, 2008). 


\section{The proposed method for equipment assessment in the context of the triple bottom line}

The proposed method for assessing the obsolescence of manufacturing equipment based on the triple bottom line was structured in seven steps, as shown in Figure 1. These steps are described below.

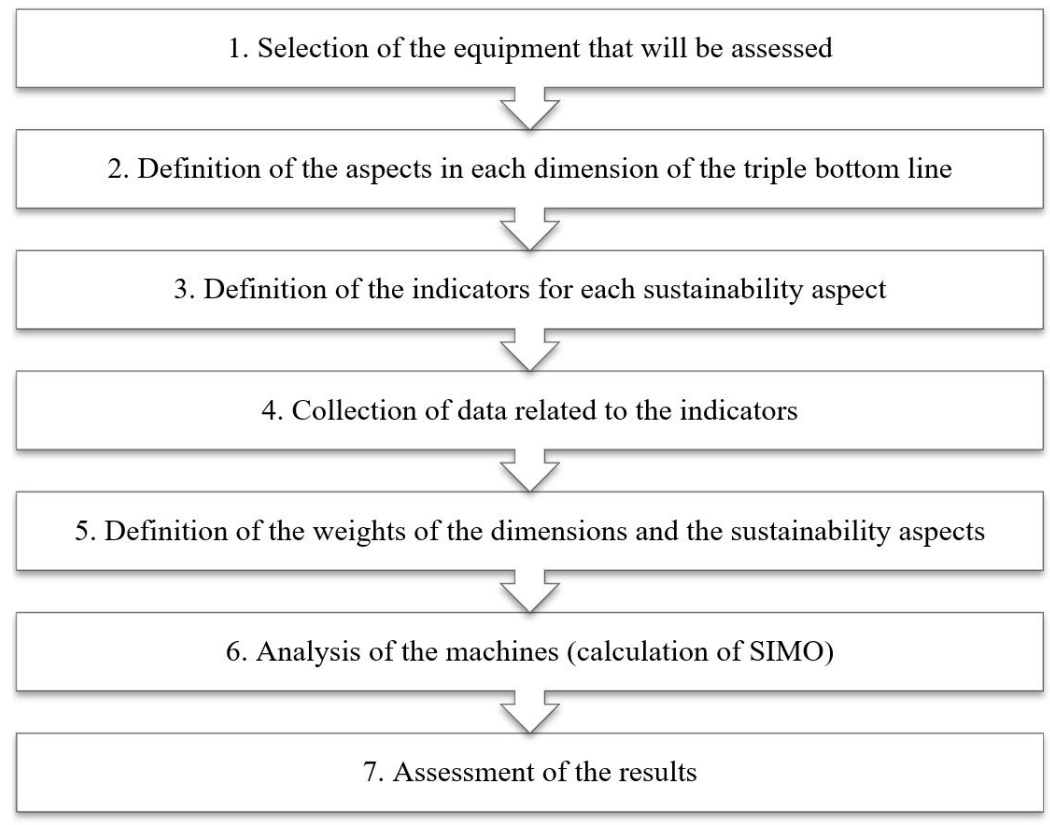

Figure 1. Steps in the proposed method.

\subsection{Step 1 - Selection of the equipment that will be assessed}

Step in which the equipment to be assessed is chosen. It is important to note that more than two pieces of equipment can be assessed simultaneously, but the definition of obsolescence is made when comparing each one with the reference equipment.

\subsection{Step 2 - Definition of the aspects in each dimension of the triple bottom line}

The proposed method is based on the analytic hierarchy process (AHP) multicriteria analysis technique, and it is important to define the hierarchical levels. In this work the assessment has four hierarchical levels, as shown in Figure 2.

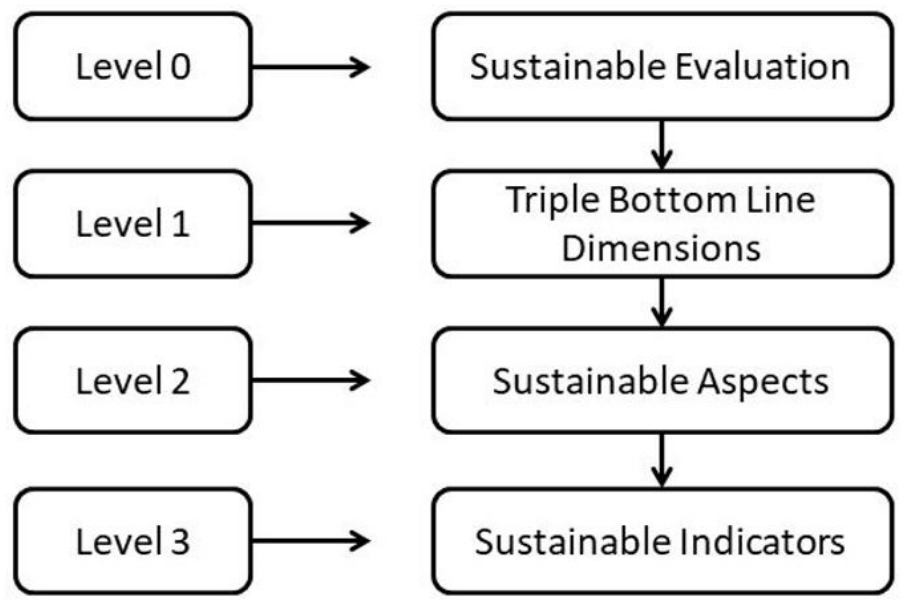

Figure 2. Structure of the proposed method. 
The sustainability assessment (level 0) is carried out following an assessment of the three dimensions of sustainability (level 1). Each dimension is assessed through sustainability aspects (level 2) which, finally, are analyzed according to their respective sustainability indicators (level 3).

The choice of levels 2 and 3 was made based on the classification used in works such as Fan et al. (2010), Caetano et al. (2012) and Bhanot et al. (2015) in which, in order to facilitate the presentation and organization of information, the authors classified indicators within sustainability aspects. That is, in each of the three dimensions there may be some aspects, and, within each aspect, there are indicators as presented in this paper.

In order to create a list to guide the definition of sustainability indicators, a brief literature survey was carried out on this topic. Based on the review by Joung et al. (2013), which covers a large number of aspects and indicators, a search for some more publications in the last years related to the triple bottom line and applied to manufacturing processes was performed. In summary, the main aspects within each of the three dimensions of sustainability are presented in Table 1.

Table 1. Aspects in dimensions of the triple bottom line that were assessed in the manufacturing context by some publications.

\begin{tabular}{|c|c|c|c|c|c|c|c|c|c|}
\hline Dimension & Aspect & 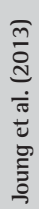 & 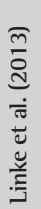 & 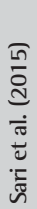 & 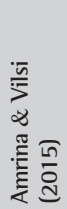 & 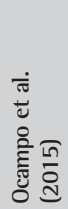 & 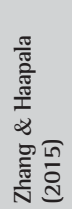 & 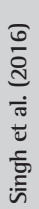 & 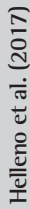 \\
\hline \multirow{4}{*}{ 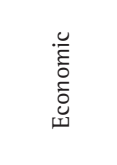 } & Cost & $x$ & $x$ & $x$ & $x$ & $x$ & $x$ & $x$ & $x$ \\
\hline & Productivity & $\mathrm{x}$ & $\mathrm{x}$ & $x$ & $\mathrm{x}$ & $x$ & $x$ & & $x$ \\
\hline & Quality & $x$ & & $x$ & & & & $x$ & $x$ \\
\hline & Guarantees and duties & $x$ & & & & & & $x$ & $\mathrm{x}$ \\
\hline \multirow{4}{*}{ 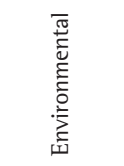 } & Production inputs consumption & $x$ & $x$ & $x$ & $x$ & $x$ & $x$ & $x$ & $x$ \\
\hline & Material usage & $\mathrm{x}$ & $x$ & $\mathrm{x}$ & $x$ & $x$ & $x$ & $x$ & $x$ \\
\hline & Land use & $x$ & & $x$ & & $x$ & & & \\
\hline & Emission, waste and effluents & $x$ & $x$ & $x$ & $x$ & $x$ & $x$ & $x$ & $x$ \\
\hline \multirow{4}{*}{$\begin{array}{l}\bar{\pi} \\
\frac{\pi}{0} \\
0\end{array}$} & Labour intensity & & $x$ & & & & $x$ & & \\
\hline & Occupational health & $\mathrm{x}$ & & $\mathrm{x}$ & $x$ & $x$ & $x$ & $x$ & $x$ \\
\hline & Worker training and satisfaction & $x$ & & $x$ & $\mathrm{x}$ & $\mathrm{x}$ & & $x$ & $x$ \\
\hline & Job safety & $x$ & & $\mathrm{x}$ & $x$ & $x$ & $x$ & $x$ & \\
\hline
\end{tabular}

In order to be used as a guideline for the choice of alternatives to be compared, a list with the main indicators used for each of the sustainability aspects was explored along with the references in Table 1. Table 2 presents some indicators for the economic dimension, separated between aspects, while Table 3 refers to the environmental dimension. Finally, Table 4 shows the list of indicators for the social dimension.

Table 2. Indicators for the economic dimension.

\begin{tabular}{ll}
\hline \multicolumn{1}{c}{ Economic Aspects } & \multicolumn{1}{c}{ Sustainability lndicators } \\
\hline Cost & $\begin{array}{l}\text { Cost of direct and indirect labor, cost of maintenance, cost of energy consumption, materials and supplies, cost of } \\
\text { inventory, etc. } \\
\text { Cycle time, production rate, overall equipment effectiveness (OEE), availability of equipment, quantity of material } \\
\text { produced, etc. }\end{array}$ \\
Quality & $\begin{array}{l}\text { Relation between non-conforming parts and good parts, capacity index and process performance }\left(P_{p} \text { and } P_{p k}\right) \text {, etc. } \\
\text { Guarantees and duties }\end{array}$ \\
\hline
\end{tabular}

Source: Joung et al. (2013), Linke et al. (2013), Sari et al. (2015), Amrina \& Vilsi (2015), Ocampo et al. (2015), Zhang \& Haapala (2015), Singh et al. (2016), Helleno et al. (2017).

Table 3. Indicators for the environmental dimension.

\begin{tabular}{ll}
\hline \multicolumn{1}{c}{ Environmental Aspects } & \multicolumn{1}{c}{ Sustainability lndicators } \\
\hline Consumption of inputs & Consumption of electric energy, gases, water, oils, etc. \\
Material usage & Raw material used, consumption of tools, filters, use of restricted materials, etc. \\
Occupied area & Total area required for installation of the machine and accessories, area required for the material being processed, etc. \\
Emissions, waste and effluents & Quantity of oil discarded, level of water loss, emission of $\mathrm{CO}_{2}$ and other gases, emission of toxic substances, etc. \\
\hline Source: Joung et al. (2013), Linke et al. (2013), Sari et al. (2015), Amrina \& Vilsi (2015), Ocampo et al. (2015), Zhang \& Haapala (2015), Singh et al. (2016), Helleno et al. (2017).
\end{tabular}


Table 4. Indicators for the social dimension.

\begin{tabular}{ll}
\hline \multicolumn{1}{c}{ Social Aspects } & \multicolumn{1}{c}{ Sustainability lndicators } \\
\hline $\begin{array}{l}\text { Labor intensity } \\
\text { Occupational health }\end{array}$ & $\begin{array}{l}\text { Energy consumed during machine operation, energy consumption in setup, etc. } \\
\text { Level of noise and vibration, degree of unhealthiness; problems of ergonomics, lighting and ventilation, etc. } \\
\text { Draining and satisfaction }\end{array}$ \\
$\begin{array}{l}\text { Degree of instruction required for the operator, hours of training, level of satisfaction to perform the task, career } \\
\text { development, etc. }\end{array}$ \\
Number of accidents at work, risk of electric, mechanical and chemical accidents, danger degree of the task, etc.
\end{tabular}

Source: Joung et al. (2013), Linke et al. (2013), Sari et al. (2015), Amrina \& Vilsi (2015), Ocampo et al. (2015), Zhang \& Haapala (2015), Singh et al. (2016), Helleno et al. (2017).

Some aspects or indicators presented in the evaluated studies are not listed because they are not focused on the equipment but in the company. For example, aspects related to community development, distance from suppliers to the plant, noise level outside the company, among others. Based on the information in Tables 1-4, together with the definition of the hierarchical levels of Figure 2, the general list of aspects and indicators for assessment of the obsolescence of manufacturing equipment was set up as shown in Figure 3.

The method also allows the entry of new aspects and indicators, according to one of the three dimensions of sustainability.

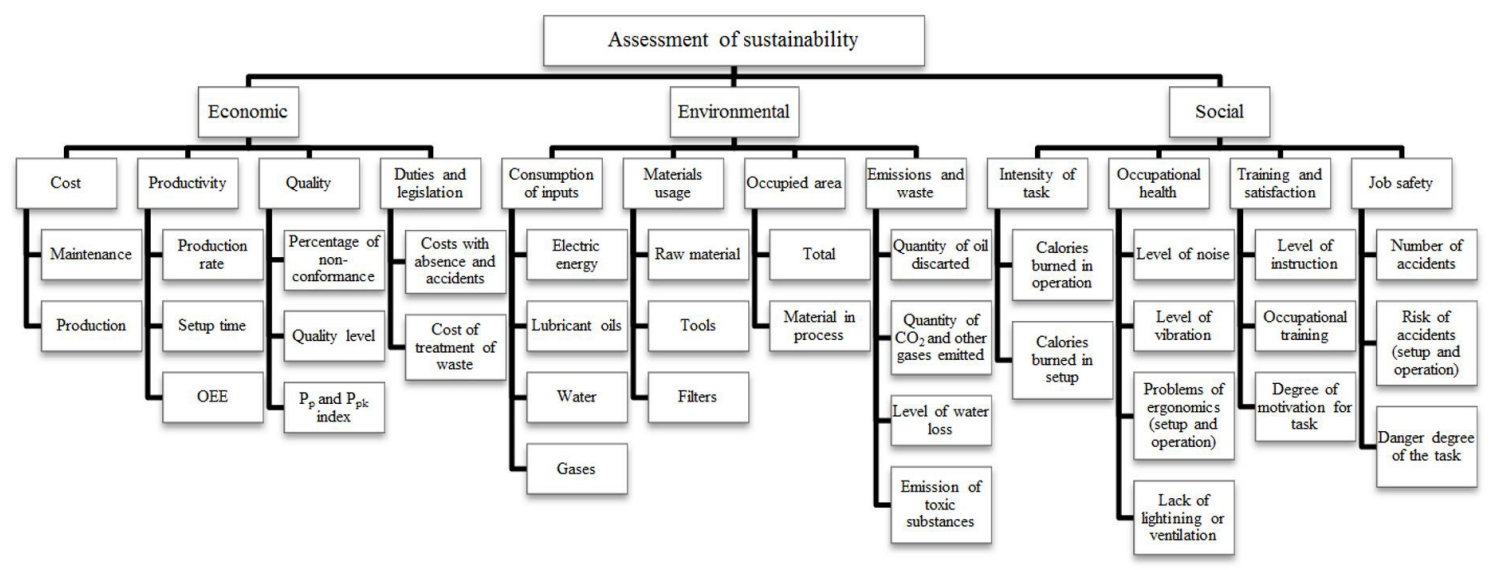

Figure 3. General list of aspects and indicators for assessment of the obsolescence of manufacturing equipment

\subsection{Step 3 - Definition of the indicators for each sustainability aspect}

In this step, representative performance indicators should be chosen for the machines being assessed. From the indicators shown in Figure 3, as previously mentioned, new indicators can be added if necessary. Some recommendations are needed:

- Similar indicators can be included in aspects listed in different dimensions. Thus, the impact of this indicator is being assessed from different perspectives. For example, electricity consumption is an important cost indicator for the economic dimension and also a source of significant environmental impact depending on the local energy matrix;

- Quantitative or qualitative indicators can be assessed.

\subsection{Step 4 -Collection of data related to chosen indicators}

Based on the chosen indicators, information is collected. Some observations are needed at this stage:

- Quantitative indicators should always be compared on a common basis and representative of actual production. For this, preferably, the main unit should be normalized by the quantity of parts produced. For example, $\mathrm{kWh} / \mathrm{part}$ or mg/part;

- The qualitative indicators will be assessed based on the fundamental scale of Saaty (2008) presented in Table 5.

It should be mentioned that the classic AHP method should be followed by comparing the criteria to ultimately obtain a global function that promotes the definitive classification of all levels and alternatives evaluated. However, the method proposed in this study uses another function to promote a definitive classification, as shown in the next steps. 
Table 5. The scale of absolute numbers.

\begin{tabular}{|c|c|c|}
\hline $\begin{array}{l}\text { Intensity of } \\
\text { Importance }\end{array}$ & Definition & Explanation \\
\hline 1 & Equal Importance & Two activities contribute equally to the objective \\
\hline 2 & Weak or slight & \\
\hline 3 & Moderate importance & Experience and judgment slightly favor one task over another \\
\hline 4 & Moderate plus & \\
\hline 5 & Strong importance & Experience and judgment strongly favor one task over another \\
\hline 6 & Strong plus & \\
\hline 7 & Very strong or demonstrated importance & A task is favored very strongly over another; its dominance demonstrated in practice \\
\hline 8 & Very, very strong & \\
\hline 9 & Extreme importance & $\begin{array}{l}\text { The evidence favoring one task over another is of the highest possible order of } \\
\text { affirmation }\end{array}$ \\
\hline $\begin{array}{l}\text { Reciprocals } \\
\text { of above }\end{array}$ & $\begin{array}{l}\text { If task } i \text { has one of the above non-zero } \\
\text { numbers assigned to it when compared with } \\
\text { task } j \text {, then } j \text { has the reciprocal value when } \\
\text { compared with } i\end{array}$ & A reasonable assumption \\
\hline $1.1-1.9$ & If the activities are very close & $\begin{array}{l}\text { It may be difficult to assign the best value, but when compared with other } \\
\text { contrasting activities the size of the small numbers would not be too noticeable, yet } \\
\text { they can still indicate the relative importance of the activities. }\end{array}$ \\
\hline
\end{tabular}

Source: Saaty (2008).

\subsection{Step 5 - Determining the weight of dimensions and aspects of sustainability}

The method requires the determination of weights for dimensions (level 1) and aspects (level 2). The weight of dimensions $(d w)$ is obtained automatically according to Equation 2, while the aspect weight (aw) is obtained according to Equation 3. The weight of dimensions is based on the number of aspects related to the dimension, compared with the total number of aspects. Likewise, the weight of the aspects is obtained by dividing the number of indicators of the aspect by the total number of dimension indicators of which the aspect is part. Thus, a possible aspect of which many indicators are assessed should have a larger weight since several items are being analyzed. Regardless of this weight suggestion, it is up to the assessor to evaluate the weights, just by noting that the sum of them has to be equal to 1.00 (or 100\%).

$$
\begin{gathered}
\text { Dimension Weight }(d w)=\frac{\text { Number of Aspects in Dimension }}{\text { Total Number of Aspects }} \\
\text { Aspect Weight }(a w)=\frac{\text { Number of Indicators in Aspects }}{\text { Number of Indicators in Dimension }}
\end{gathered}
$$

\subsection{Step 6 - Analysis of the machines}

At this stage the equipment is assessed and the value of the Sustainability Index for Machine Obsolescence (SIMO) is determined. For this, the comparison by the AHP method for each of the chosen qualitative indicators is used as the basis, and the quantitative indicators are normalized. This normalization is done for each machine $i$, according to Equation 4. An important issue concerns the nature of the indicators, since, for each indicator, a larger value indicates that the equipment has a higher degree of obsolescence. Thus, in the case where a lower value of an indicator represents a machine with greater obsolescence (for example, "production rate"), the reciprocal of the value for each equipment must be obtained before normalization, according to Equation 5 , and this should be the value used in Equation 6.

$$
\begin{gathered}
\text { Normalized IndicatorValue }\left(\text { niv }_{i}\right)=\frac{\text { IndicatorValue }\left(i v_{i}\right)}{\sum i v_{i}} \\
\text { Reciprocal IndicatorValue }\left(i i v_{i}\right)=\frac{1}{i v_{i}} \\
\text { Normalized Reciprocal IndicatorValue }\left(\text { niiv }_{i}\right)=\frac{\text { Reciprocal IndicatorValue }\left(i i v_{i}\right)}{\sum i i v_{i}}
\end{gathered}
$$


The normalized values obtained by Equation 4 or Equation 6 provide the Final Indicator Value $\left(f i v_{i}\right)$ for each of the $i$ machines. The value for each aspect is obtained based on the average of the final values of the indicators multiplied by the weight of the aspect in question (Equation 7).

$$
\operatorname{AspectValue}\left(a v_{i}\right)=a w x \frac{\sum f i v_{i}}{\text { Number of indicators in aspect }}
$$

The average of the values of the aspects multiplied by the weight of each dimension gives the value for each dimension, as shown in Equation 8.

$$
\text { DimensionValue }\left(d v_{i}\right)=d w x \frac{\sum a v_{i}}{\text { Number of aspects in dimension }}
$$

Finally, the sum of the values of the dimensions corresponds to the result of the sustainability assessment for each of the $i$ machines, as shown in Equation 9.

$$
\text { Sustainability Index for MachineObsolescence }\left(\operatorname{SIMO}_{i}\right)=d v_{\text {eco }}+d v_{\text {env }}+d v_{\text {soc }_{i}}
$$

\subsection{Step 7 - Assessment of results}

The last step of the method corresponds to an assessment of the results obtained. The machine that has the highest SIMO value, calculated in step 6, has greater obsolescence based on the triple bottom line. As a guideline, a percentage analysis of the value of each of the machines can be made to facilitate the understanding of the result, as well as a comparison in each dimension to expose the areas with the greatest problems.

The fact of having greater obsolescence in terms of sustainability does not mean that the machine should be replaced. This diagnosis is made by comparing a Sustainability Index for Machine Obsolescence (SIMO) with the ratio between the discounted payback (for example, for the purchase of new equipment or even a retrofitting of the equipment under analysis) and the company's payback policy. Figure 4 illustrates how this comparison is made.

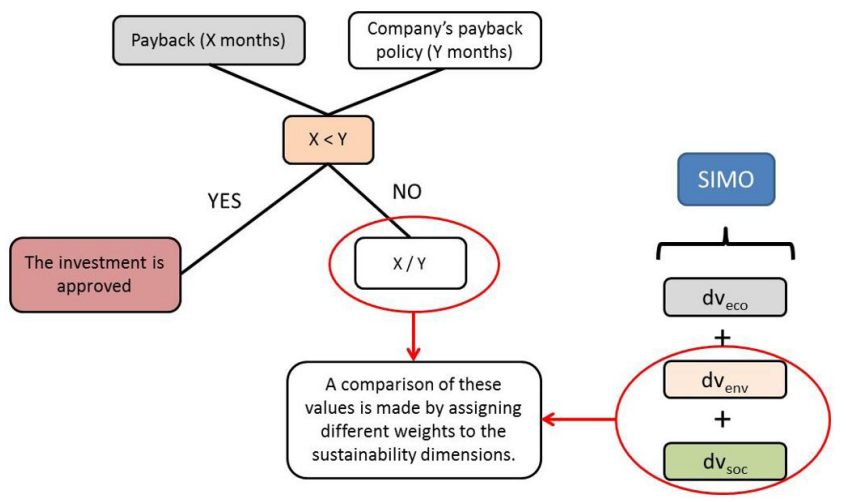

Figure 4. Illustration of the comparison between SIMO and payback

In this way, it is possible to carry out another type of analysis for situations where there is no economic justification for the approval of the investment, i.e. for situations where the calculated discounted payback period (X months) is greater than the return on investment policy ( $\mathrm{Y}$ months). In this case, the assessor can analyze which combinations of weights of the dimensions $(d w)$ represent the obsolescence of the machine "i" compared with the reference machine "ref" as a function of the ratio between $\left(d v_{e n v}+d v_{s o c}\right)$ and SIM0, compared with the ratio between payback and payback policy $(\mathrm{X} / \mathrm{Y}) . d v_{\text {eco }}$ is not considered in the numerator because the assessment of the return on investment period is an indirect representation of the economic dimension that should not be reconsidered. Equation 10 shows this analysis.

$$
\frac{\left(d v_{\text {env }}+d v_{\text {soc }}\right)_{i}-\left(d v_{\text {env }}+d v_{\text {soc }}\right)_{\text {ref }}}{\text { SIMO ref }} \geq \frac{\text { Payback-Payback's policy }}{\text { Payback's policy }}
$$




\section{Results}

The proposed method was applied in a large company that manufactures electric machines (motors, generators and transformers) located in the state of Santa Catarina, southern Brazil. For the manufacture of electric motors' laminations, as well as small electronics components, large-scale production equipment is used, known as high-performance lines with a high production rate (stamping speed), also called high speed stamping press lines (Hoffman \& Kasparbauer, 1998). The company has a production line with more than 15 high speed presses that process together more than 300 tons of steel per day. According to step 1 of the method, two machines were chosen from the same manufacturer, whose main data are shown in Table 6.

Table 6. Data related to the high speed presses studied in this work.

\begin{tabular}{|c|c|c|}
\hline Specifications & Press A & Press B \\
\hline Installation year & 1989 & 2012 \\
\hline Model & A2 $400-2.6$ & SAL $400-2.8$ \\
\hline Drive type & \multicolumn{2}{|c|}{ Flywheel drive } \\
\hline Capacity & \multicolumn{2}{|c|}{$4000 \mathrm{kN}$} \\
\hline Slide stroke & \multicolumn{2}{|c|}{$35 \mathrm{~mm}$} \\
\hline Stroking speed & 80 - 250 strokes per minute & 80 - 400 strokes per minute \\
\hline Stacking device for laminations & No & Yes \\
\hline Dynamic mass counterbalance & No & Yes \\
\hline Area of bolster plate and slide & $2600 \times 1200 \mathrm{~mm}$ & $2800 \times 1200 \mathrm{~mm}$ \\
\hline
\end{tabular}

Steps 2 and 3 were performed with the help of the people directly involved with this manufacturing process in the company. No additional aspects were added to the already pre-defined 12 aspects (shown in Table 1), but some indicators were included or simply adapted. The units of the indicators should follow magnitudes already regularly used. It was also decided that some indicators would be assessed in a qualitative way, and they receive the word "qualitative" in the field related to their unit as shown in Table 7.

Table 7. Data to assess the sustainability of the two machines studied in this work.

\begin{tabular}{|c|c|c|c|c|c|}
\hline Dimension & Aspect & Indicator & Unit & Press A & Press B \\
\hline \multirow{8}{*}{ Economic } & \multirow{3}{*}{ Cost } & Maintenance & $\$ /$ part & 0.0132 & 0.0045 \\
\hline & & Production & $\$ /$ part & 0.0442 & 0.0103 \\
\hline & & Production rate & parts/min & 100 & 187 \\
\hline & \multirow[t]{2}{*}{ Productivity } & Setup time & $\min$ & 64 & 57 \\
\hline & & Operating yield (OEE) & $\%$ & 44 & 60 \\
\hline & Quality & Percentage of nonconformance & $\%$ & 1.89 & 0.67 \\
\hline & \multirow{2}{*}{ Duties and legislation } & Cost of absence and accidents & $\$ / 1000$ parts & 0.2766 & 0.1471 \\
\hline & & Replacement cost of scrap & $\$ / 1000$ parts & 0.9627 & 0.1819 \\
\hline \multirow{9}{*}{ Environmental } & \multirow{3}{*}{ Consumption of inputs } & Electrical energy & $\mathrm{kWh} /$ part & 0.0188 & 0.0113 \\
\hline & & Stamping fluid & $\mathrm{ml} /$ part & 0.2667 & 0.3200 \\
\hline & & Lubricating oils & $\mathrm{ml} /$ part & 0.0020 & 0.0005 \\
\hline & \multirow{2}{*}{ Material usage } & Filters & units/1 million parts & 0.0795 & 0.0271 \\
\hline & & Tools & $\mathrm{mm} / 100.000$ parts & 0.6667 & 0.7692 \\
\hline & \multirow{2}{*}{ Occupied area } & Total & $\mathrm{m}^{2}$ & 78 & 105 \\
\hline & & Material being processed & $m^{2}$ & 19.5 & 28.5 \\
\hline & \multirow{2}{*}{ Emissions and waste } & Quantity of $\mathrm{CO}_{2}$ & $\mathrm{~g} /$ part & 2.0829 & 1.2558 \\
\hline & & Non-reused fluids & $\mathrm{ml} /$ part & 0.2347 & 0.2880 \\
\hline \multirow{11}{*}{ Social } & \multirow{2}{*}{ Intensity of task } & Calories burned in operation & qualitative & 0.6667 & 0.3333 \\
\hline & & Calories burned in setup & qualitative & 0.5238 & 0.4762 \\
\hline & \multirow{3}{*}{ Occupational health } & Level of noise & $\mathrm{dB}$ & 106 & 95 \\
\hline & & Ergonomics (setup) & qualitative & 0.4762 & 0.5238 \\
\hline & & Ergonomics (operation) & qualitative & 0.2500 & 0.7500 \\
\hline & \multirow{3}{*}{$\begin{array}{l}\text { Worker training and } \\
\text { satisfaction }\end{array}$} & Level of instruction & qualitative & 0.4167 & 0.5833 \\
\hline & & Occupational training & hr/operator/year & 100 & 150 \\
\hline & & Degree of motivation for the task & qualitative & 0.3333 & 0.6667 \\
\hline & \multirow{3}{*}{ Job safety } & Number of accidents & accidents/year & 0.0318 & 0.0135 \\
\hline & & Risk of accidents (operation and setup) & qualitative & 0.6000 & 0.4000 \\
\hline & & Risk of accidents (maintenance) & qualitative & 0.7500 & 0.2500 \\
\hline
\end{tabular}


Some indicators related to progressive stamping have not been listed because they relate only to the tool (progressive stamping die) and not to the presses themselves. For example, the indicators referring to the raw material and its use depend on the design solutions for the tools. No indicator of water consumption was included, since it is included in the consumption of cutting fluid. Table 7 shows all the indicators chosen for the evaluation of the two presses, and some details of the dimensions are given below.

(a) Economic Dimension:

- The "maintenance costs" indicator includes the costs related to maintenance work, exchanged parts and stopped machine due to corrective maintenance.

- The "production costs" indicator represents, in addition to the cost of direct and indirect labor, the costs of electricity, used tools, machine depreciation, etc.

- For the indicators "production rate" and "setup time" the values referring to the same parts produced in the presses being assessed should be compared, in order to avoid the influence of the variation of the tool.

- The "percentage of nonconformance" is related to the number of parts outside the specification that will have to be rejected, as well as to those that need rework.

(b) Environmental Dimension:

- The "tooling" indicator represents the tool wear found on each of the different machines being assessed. It is measured at each regrinding of the stamping tool.

- For the assessment of indicators related to "material in process", in the aspect "occupied area", it should be based on the same type of product so that very different sizes of parts are not assessed.

\section{(c) Social Dimension:}

- The "level of instruction" indicator is related to the educational content required for the operation of the high speed presses.

- For the indicator "degree of motivation for the task" it is intended to analyze the interest and motivation of the operators due to the operational difference and complexity of the presses and their accessories.

- The "number of accidents" indicator should cover all situations that cause (or not) removal from the task.

Following the proposed method, Step 4 corresponds to the collection of information. The quantitative indicators were measured and/or assessed based on the data collected by the machine monitoring system, and the qualitative indicators were assessed based on the knowledge of the company's employees. The last two columns of Table 7 present the result of these measurements and/or assessments.

The description of the indicators was presented in step 3, but the following comments are necessary for a better understanding of the assessment:

- The assessment period was 18 months;

- For the "production rate" and "setup time" indicators, the values referring to the same progressive stamping dies used on these two machines were compared;

- The "percentage of nonconformance " indicator was obtained based on an indicator already monitored by the company;

- The "quantity of $\mathrm{CO}_{2}$ emitted" was estimated based on the electric energy consumption of each piece of equipment;

- With regard to the assessment of a quantitative indicator whose highest value corresponds to a greater obsolescence of the press, an example of calculation using Equation 4 for the indicator "maintenance" of the aspect "costs" is shown in Table 8.

- In the case of a quantitative indicator whose lower value corresponds to a greater obsolescence of the press, an example of calculations using Equations 5 and 6 for the indicator "rate of production" (of aspect "productivity") results in the values shown in the last two columns of Table 9.

- In the case of a qualitative indicator in which its larger value corresponds to a greater obsolescence of the press, the example of the indicator "risk of accidents in the operation" is shown. In this case, Press A has a greater risk of causing accidents in the operation than Press B. Thus, the priority vectors of the AHP method are determined, which are considered the normalized values (Equation 4), and they are shown in the last column of Table 10. 
- In the case of a qualitative indicator whose lower value corresponds to a greater obsolescence of the press, the example of the indicator "ergonomics in setup" is presented. In this case, it was observed that Press A is somewhat less ergonomic than Press B. Table 11 shows the values assigned to the presses as well as priority vectors applied. Equations 5 and 6 are applied to determine the normalized values.

The next step corresponds to the determination of the weights of aspects and sustainability indicators (Step 5). Using Equations 2 and 3 the values shown in Table 12 are obtained.

Table 8. Example of quantitative indicator assessment - case 1.

\begin{tabular}{ccc}
\hline Maintenance Costs & Indicator Value (iv) $(\$ /$ part $)$ & Normalized Indicator Value $($ niv $)$ \\
\hline Press A & 0.0132 & 0.7466 \\
Press B & 0.0045 & 0.2534 \\
\hline
\end{tabular}

Table 9. Example of quantitative indicator assessment - case 2.

\begin{tabular}{cccc}
\hline Production rate & Indicator Value (iv) (parts/min) & Reciprocal Indicator Value (iiv) & $\begin{array}{c}\text { Normalized Reciprocal Indicator } \\
\text { Value (niv) }\end{array}$ \\
\hline Press A & 100 & 0.0100 & 0.6512 \\
Press B & 187 & 0.0054 & 0.3488 \\
\hline
\end{tabular}

Table 10. Example of qualitative indicator assessment - case 1.

\begin{tabular}{cccc}
\hline Risk of accidents in the operation & Press A & Press B & Priorities (niv) \\
\hline Press A & 1.0 & 1.5 & 0.6000 \\
Press B & $1 / 1.5$ & 1.0 & 0.4000 \\
\hline
\end{tabular}

Table 11. Example of qualitative indicator assessment - case 2.

\begin{tabular}{ccccc}
\hline Ergonomics (setup) & Press A & Press B & Priorities & (niiv) \\
\hline Press A & 1.0 & $1 / 1.1$ & 0.4762 & 0.5238 \\
Press B & 1.1 & 1.0 & 0.5238 & 0.4762 \\
\hline
\end{tabular}

Table 12. Weights for dimensions and aspects.

\begin{tabular}{|c|c|c|c|}
\hline Dimension & Weight $(d w)$ & Aspects & Weight (aw) \\
\hline \multirow{4}{*}{ Economic } & \multirow{4}{*}{$1 / 3$} & Costs & 0.250 \\
\hline & & Productivity & 0.375 \\
\hline & & Quality & 0.125 \\
\hline & & Guarantees and duties & 0.250 \\
\hline \multirow{4}{*}{ Environmental } & \multirow{4}{*}{$1 / 3$} & Production inputs consumption & 0.334 \\
\hline & & Material usage & 0.222 \\
\hline & & Land use & 0.222 \\
\hline & & Emissions, waste and effluents & 0.222 \\
\hline \multirow{4}{*}{ Social } & \multirow{4}{*}{$1 / 3$} & Labor intensity & 0.181 \\
\hline & & Occupational health & 0.273 \\
\hline & & Worker training and satisfaction & 0.273 \\
\hline & & Job safety & 0.273 \\
\hline
\end{tabular}

In Step 6 the calculations are made for the final assessment of the presses. Using Equations 4, 5 and 6, the reciprocal of each value shown in Table 7 (if necessary) and normalized. Table 13 shows the result of the values of the aspects ( $a v)$ obtained by Equation 7. The values for each of the three dimensions $(d v)$, according to Equation 8, as well as the value of the Sustainability Index for Machine Obsolescence (SIMO) for the presses (Equation 9) are also presented.

Step 7 begins with the sustainability assessment in each dimension, where it was observed that press A presented the worst result for the economic dimension (56\% worse), followed by the social dimension (40\%) and $21 \%$ for the environmental dimension in comparison with the reference press. In the environmental dimension, the difference was less because press A (20 years older than press B) required a smaller installed area and had less tool wear, since it ran at speeds much lower than the speeds of the newer press.

In the overall assessment press A's Sustainability Index for Machine Obsolescence is 67\% higher than the value found for press B. This fact was already expected due to the difference of more than 20 years between these machines and the different installed resources. 
Following Step 7, the obsolescence of press A was analyzed based on the triple bottom line, with the help of some company information (Table 14).

Applying Equation 1, the discounted payback time is equal to 76 months, which is $27 \%$ higher than the payback policy adopted by the company for this type of investment. However, as a sequence of step 7 different weight combinations were assigned to the dimensions using Equation 10 in the percentage form and considering press B as reference. As shown in Table 15, it can be observed that a weight of 40\% for the economic dimension, $30 \%$ for the environmental dimension and 30\% for the social dimension results in the press being diagnosed as obsolete from the sustainability standpoint, since the value was above $27 \%$.

Table 13. Dimensions, aspects, and final assessment values for the two presses.

\begin{tabular}{|c|c|c|c|}
\hline Dimension & Aspects & Press A & Press B \\
\hline \multirow{5}{*}{ Economic } & Costs & 0.1952 & 0.0548 \\
\hline & Productivity & 0.2196 & 0.1554 \\
\hline & Quality & 0.0924 & 0.0326 \\
\hline & Guarantees and duties & 0.1867 & 0.0633 \\
\hline & Economic value & 0.0578 & 0.0255 \\
\hline \multirow{4}{*}{ Environmental } & Production inputs consumption & 0.2075 & 0.1265 \\
\hline & Material usage & 0.1343 & 0.0877 \\
\hline & Land use & 0.0924 & 0.1296 \\
\hline & Emissions, waste and effluents & 0.1191 & 0.1029 \\
\hline \multirow{7}{*}{ Social } & Environmental value & 0.0483 & 0.0382 \\
\hline & Labor intensity & 0.1077 & 0.0733 \\
\hline & Occupational health & 0.1639 & 0.1091 \\
\hline & Worker training and satisfaction & 0.1684 & 0.1047 \\
\hline & Job safety & 0.1867 & 0.0863 \\
\hline & Social value & 0.0522 & 0.0311 \\
\hline & SIMO & 0.1583 & 0.0948 \\
\hline
\end{tabular}

Table 14. Data related to the discounted payback assessment of high speed press A.

\begin{tabular}{cc}
\hline Total investment & $\$ 8,423,000$ \\
\hline Press (new) & $\$ 6,400,000$ \\
Taxes and import charges & $\$ 1,373,000$ \\
Transport and commissioning & $\$ 250,000$ \\
Devices and accessories & $\$ 400,000$ \\
Cash savings & $\$ 160,000 /$ month \\
Opportunity cost & $1 \% /$ month \\
Company's payback policy & 60 months \\
\hline
\end{tabular}

Table 15. Sustainable obsolescence assessment of press A.

\begin{tabular}{|c|c|c|c|}
\hline \multicolumn{3}{|c|}{ Dimension weights (\%) } & \multirow{2}{*}{$\begin{array}{c}\text { Env + Soc } \\
\text { Obsolescence }\end{array}$} \\
\hline Economic & Environmental & Social & \\
\hline 80 & 10 & 10 & $11.4 \%$ \\
\hline 60 & 20 & 20 & $21.4 \%$ \\
\hline 40 & 30 & 30 & $30.2 \%$ \\
\hline
\end{tabular}

There are other combinations of weights which satisfy the comparison of Equation 10. In order to perform a sensitivity analysis of the influence of the variation of the dimensions weights, Figure 5 shows in the gray highlighted region options of combinations of weights for environmental and social dimensions that result in press A being considered obsolete. The weight of the economic dimension is not explicit, but it was used as the complementary value of the other dimensions to reach the sum of $100 \%$. In addition, blank cells represent not possible combinations, where the sum of the weights exceeds $100 \%$.

Finally, the final assessment shows that even if there is no economic justification for replacing the press A, based on the assessment of the financial return on investment, the press can be considered obsolete from a sustainable point of view due to its environmental and social performance. 


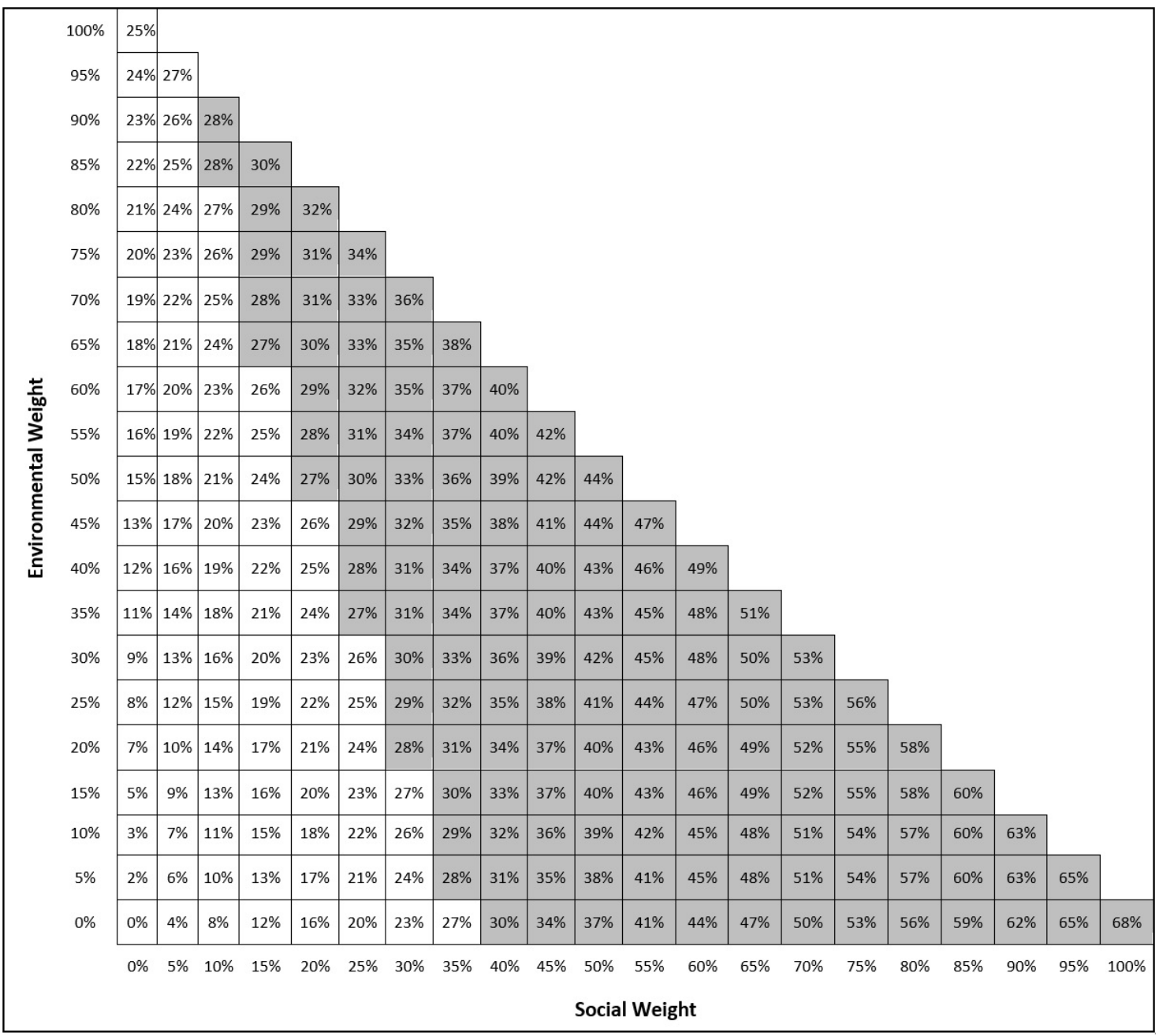

Figure 5. Sustainable obsolescence assessment: different combinations of weights that result in press A being considered obsolete.

\section{Conclusions}

The proposed method sought to provide the assessment of equipment based on indicators related to the triple bottom line. The method allows the assessor to include new criteria for the assessment, as well as to analyze qualitative information about the equipment under analysis.

As for the assessment of obsolescence, the study presented a broader view of the traditional analysis of the economic performance of machines, providing an expansion for indicators related to the environmental and social dimensions. In this way, the assessor is allowed to decide on the replacement of equipment based on an assessment in which sustainability is taken into account.

With regard to the assessment of high speed presses, an unexplored study of such equipment was presented, which are machines that work in 24-hour production daily in a large company. Several indicators that are considered in this work have an effective value only when assessed in a large-scale production situation.

There is no restriction for the application of the proposed method in other types of machines and, therefore, as a future work, it is suggested the application of the method in different types of equipment. It is also recommended the development of software that allows the creation of a database with the collected information, as well as a method to eliminate human intervention in the analysis of the weights that indicate the obsolescence of the machine in the sustainability point of view. In addition, future work may contemplate different techniques of financial analysis of the investment, as well as include variable cash savings over time due to variations in maintenance cost, variations in productivity, and costs resulting from nonconformances in manufactured parts. 


\section{References}

Amrina, E., \& Vilsi, A. L. (2015). Key performance indicators for sustainable manufacturing assessment in cement industry. Procedia CIRP, 26, 19-23. http://dx.doi.org/10.1016/j.procir.2014.07.173.

Bhanot, N., Rao, P. V., \& Deshmukh, S. G. (2015). Sustainability assessment framework for a manufacturing firm: an exploratory study. Journal of Practice Management, 39(2), 36-46.

Brockhaus, S., Fawcett, S., Kersten, W., \& Knemeyer, M. (2016). A framework for benchmarking product sustainability efforts: Using systems dynamics to achieve supply chain alignment. Benchmarking, 23(1), 127-164. http://dx.doi.org/10.1108/BlJ-09-2014-0093.

Brundtland, G. H. (1987). Report of the World Commission on environment and development: “Our common future”. New York: United Nations.

Caetano, M., Araujo, J. B., \& Amaral, D. C. (2012). A framework for the application of eco-efficiency to the technology development process. Journal of Technology Management \& Innovation, 72), 28-38. http://dx.doi.org/10.4067/S0718-27242012000200003.

Caputo, A. C., Pelagagge, P. M., \& Salini, P. (2013). AHP-based methodology for selecting safety devices of industrial machinery. Safety Science, 53, 202-218. http://dx.doi.org/10.1016/j.ssci.2012.10.006.

Chaim, O., Muschard, B., Cazarini, E., \& Rozenfeld, H. (2018). Insertion of sustainability performance indicators in an industry 4.0 virtual learning environment. Procedia Manufacturing, 21, 446-453. http://dx.doi.org/10.1016/j.promfg.2018.02.143.

Cucchiella, F., D’Adamo, 1., Rosa, P., \& Terzi, S. (2016). Automotive printed circuit boards recycling: an economic analysis. Journal of Cleaner Production, 121, 130-141. http://dx.doi.org/10.1016/j.jclepro.2015.09.122.

Elkington, J. (1999). Cannibals with forks: triple bottom line of 21st century business. Oxford, UK: Capstone.

Fan, C., Carrel, J. D., \& Zhang, H.-C. (2010 May 17-19). An investigation of indicators for measuring sustainable manufacturing. In International Symposium on Sustainable Systems and Technology (pp. 1-5). IEEE: Arlington, USA.

Guo, R. (2017). Industrialization and Technological Progress. In Guo R. How the chinese economy works (4th ed., pp. 341-371). Palgrave Macmillan. http://dx.doi.org/10.1007/978-3-319-32306-0_11.

Haanaes, K., Balagopal, M., Kong, M. T., Velken, 1., Arthur, D., Hopkins, M. S., \& Kruschwitz, N. (2011). New sustainability study: the 'embracers' seize advantage. Cambridge: MIT Sloan Management Review. Retrieved in 13 July 2017, from http://sloanreview.mit. edu/paper/new-sustainability-study-the-embracers-seize-advantage/

Hallstedt, S. 1., Thompson, A. W., \& Lindahl, P. (2013). Key elements for implementing a strategic sustainability perspective in the product innovation process. Journal of Cleaner Production, 51, 277-288. http://dx.doi.org/10.1016/j.jclepro.2013.01.043.

Hartman, J. C., \& Murphy, A. (2006). Finite-horizon equipment replacement analysis. IlE Transactions, 38(5), 409-419. http://dx.doi. org/10.1080/07408170500380054.

Helleno, A. L., Moraes, A. J. 1., \& Simon, T. S. (2017). Integrating sustainability indicators and lean manufacturing to assess manufacturing processes: Application case studies in Brazilian industry. Journal of Cleaner Production, 153, 405-416. http://dx.doi.org/10.1016/j. jclepro.2016.12.072.

Ho, W., \& Ma, X. (2018). The state-of-the-art integrations and applications of the analytic hierarchy process. European Journal of Operational Research, 267(2), 399-414. http://dx.doi.org/10.1016/j.ejor.2017.09.007.

Hoffman, H., \& Kasparbauer, M. (1998). Metal Forming Handbook (291 p.). Germany: Goeppingen.

Huang, l. B., Keisler, J., \& Linkov, 1. (2011). Multi-criteria decision analysis in environmental sciences: ten years of applications and trends. The Science of the Total Environment, 409(19), 3578-3594. http://dx.doi.org/10.1016/j.scitotenv.2011.06.022. PMid:21764422.

Jan, 1. (2017). Discounted Payback Period. Retrieved in 2017, October 20, from https://accountingexplained.com/managerial/capitalbudgeting/discounted-payback-period/

Joung, C. B., Carrell, J., Sarkar, P., \& Feng, S. C. (2013). Categorization of indicators for sustainable manufacturing. Ecological Indicators, 24, 148-157. http://dx.doi.org/10.1016/j.ecolind.2012.05.030.

Kleindorfer, P. R., Singhal, K., \& Van Wassenhove, L. (2005). Sustainable operations management. Production and Operations Management, 14(4), 482-492. http://dx.doi.org/10.1111/j.1937-5956.2005.tb00235.x.

Kluczek, A. (2016). Application of multi-criteria approach for sustainability assessment of manufacturing processes. Management and Production Engineering Review, 73), 62-78. http://dx.doi.org/10.1515/mper-2016-0026.

Kushwaha, G. S., \& Sharma, N. K. (2016). Green initiatives: a step towards sustainable development and firm's performance in the automobile industry. Journal of Cleaner Production, 121, 116-129. http://dx.doi.org/10.1016/j.jclepro.2015.07.072.

Lawrence, C. L., \& Tanchoco, J. M. A. (1990). Multiple machine replacement analysis. Journal of Engineering Costs and Production Economics, 20(3), 265-275. http://dx.doi.org/10.1016/0167-188X(90)90074-R.

Linke, B. S., Corman, G. J., Dornveld, D. A., \& Tönissen, S. (2013). Sustainability indicators for discrete manufacturing processes applied to grinding technology. Journal of Manufacturing Systems, 32(4), 556-563. http://dx.doi.org/10.1016/j.jmsy.2013.05.005.

Morioka, S. N., \& Carvalho, M. M. (2016). A sistematic literature review towards a conceptual framework for integrating sustainability performance into business. Journal of Cleaner Production, 136, 134-146. http://dx.doi.org/10.1016/j.jclepro.2016.01.104.

Ocampo, L. A. (2015). A hierarchical framework for index computation in sustainable manufacturing. Advances in Production Engineering \& Management, 10, 40-50. http://dx.doi.org/10.14743/apem2015.1.191.

Ocampo, L. A., Vergara, V. G., Impas, C., Tordillo, J. A., \& Pastoril, J. (2015). Identifying critical indicators in sustainable manufacturing using analytic hierarchy process (AHP). Journal of Manufacturing and Industrial Engineering, 14(3-4), 1-8. http://dx.doi.org/10.12776/ mie.v14i3-4.444.

Oliveira, J. Z., \& Duque, J. (2011). Operational asset replacement strategy: A real options approach. European Journal of Operational Research, 210(2), 318-325. http://dx.doi.org/10.1016/j.ejor.2010.09.011.

Ortas, E., Gallego-Alvarez, 1., \& Álvarez Etxeberria, 1. (2015). Financial factors influencing the quality of corporate social responsibility and environmental management disclosure: A quantile regression approach. Corporate Social Responsibility and Environmental Management, 22(6), 362-380. http://dx.doi.org/10.1002/csr.1351. 
Paine, L. S. (2014). Sustainability in the board room. Harvard Business Review, 92(7), 86-94.

Panneerselvam, R. (2012). Engineering Economics (13th ed.). New Delhi, India: PHI Learning Private Limited.

Pimenta, H. C. D., \& Gouvinhas, R. P. (2012). A produção mais limpa como ferramenta da sustentabilidade empresarial: um estudo no estado do Rio Grande do Norte. Production, 22(3), 462-476. http://dx.doi.org/10.1590/S0103-65132012005000043.

Pingle, P. (2015). Selection of obsolescence resolution strategy based on a multi criteria decision model. lowa, USA: lowa State University. http://dx.doi.org/10.31274/etd-180810-4543.

Qorri, A., Mujkic, Z., \& Kraslawski, A. (2018). A conceptual framework for measuring sustainability performance of supply chains. Journal of Cleaner Production, 189, 570-584. http://dx.doi.org/10.1016/j.jclepro.2018.04.073.

Ravi, V. (2015). Industrial Engineering and Management. Delhi, Índia: PHI Learning. Capstone.

Robinson, S. L. (2013). An environmental and economic trade-off analysis of manufacturing process chains to inform decision making for sustainability (Doctor thesis). University of California, Berkeley, USA. Retrieved in 2017, June 27, from http://escholarship.org/ uc/item/1513r3t9\#page-1

Saad, M. H., Nazzal, M. A., \& Darras, B. M. (2019). A general framework for sustainability assessment of manufacturing processes. Ecological Indicators, 97, 211-224. http://dx.doi.org/10.1016/j.ecolind.2018.09.062.

Saaty, T. L. (1987). The analytic hierarchy process - What it is and how it is used. Mathematical Modelling, 9(3-5), 161-176. http:// dx.doi.org/10.1016/0270-0255(87)90473-8. PMid:12312762.

Saaty, T. L. (2008). Decision making with the analytical hierarchy process. International Journal of Services Sciences, 1(1), 83-98. http:// dx.doi.org/10.1504/IJSSCl.2008.017590.

Sari, E., Shaharoun, A. M., Ma'aram, A., \& Yazid, A. M. (2015). Sustainable maintenance performance measures: a pilot survey in Malaysian automotive companies. Procedia CIRP, 26, 443-448. http://dx.doi.org/10.1016/j.procir.2014.07.163.

Sénéchal, 0. (2017). Research directions for integrating the triple bottom line in maintenance dashboards. Journal of Cleaner Production, 142, 331-342. http://dx.doi.org/10.1016/j.jclepro.2016.07.132.

Singh, S., Olugu, E. U., \& Musa, S. N. (2016). Development of sustainable manufacturing decision making models for small and medium enterprises. Procedia CIRP, 40, 608-613. http://dx.doi.org/10.1016/j.procir.2016.01.142.

Tan, C. H., \& Hartman, J. C. (2010). Equipment replacement analysis with an uncertain finite horizon. IIE Transactions, 42(5), $342-353$. http://dx.doi.org/10.1080/07408170903394363.

Teles, C. D., Dutra, C. C., Ribeiro, J. L. D., \& Guimarães, L. B. M. (2016). Uma proposta para avaliação da sustentabilidade socioambiental utilizando suporte analítico e gráfico. Production, 26(2), 417-429. http://dx.doi.org/10.1590/0103-6513.0638T6.

Thanki, S., Govindan, K., \& Thakkar, J. (2016). An investigation on lean-green implementation practices in Indian SMEs using analytical hierarchy process (AHP) approach. Journal of Cleaner Production, 135, 284-298. http://dx.doi.org/10.1016/j.jclepro.2016.06.105.

Trianni, A., Cagno, E., Neri, A., \& Howard, M. (2019). Measuring industrial sustainability performance: Empirical evidence from ltalian and German manufacturing small and medium enterprises. Journal of Cleaner Production, 229, 1355-1376. http://dx.doi.org/10.1016/j. jclepro.2019.05.076.

United Nations (2015a). Sustainable Development Goals. United Stations. Retrieved in 2017, September 20, from www.un.org/ sustainabledevelopment/ sustainable-development-goals/

United Nations (2015b). Sustainable Development Goals. Goal 12: Ensure sustainable consumption and production patterns. United Stations. Retrieved in 2017, September 22, from www.un.org/sustainabledevelopment/sustainable-consumption-production/

Zhang, H., \& Haapala, K. R. (2015). Integrating sustainable manufacturing assessment into decision making for a production work cell. Journal of Cleaner Production, 105, 52-63. http://dx.doi.org/10.1016/j.jclepro.2014.01.038. 